\title{
Morphologic, Palynologic, and Phylogenetic Relationships of Acantholimon Species (Plumbaginaceae) Sharing Similar Habitats
}

\author{
Mevlüde Alev ATEŞ¹, Bahar KAPTANER İĞCI², Tuğrul Selçuk KÖRÜKLÜ3 ${ }^{3}$ Ahter FIŞNE², Zeki AYTAÇ² \\ ${ }^{1}$ Department of Agricultural Biotechnology, Faculty of Agriculture, Kırşehir Ahi Evran University, Kırşehir, Turkey; \\ ${ }^{2}$ Department of Biology, Faculty of Science, Gazi University, Ankara, Turkey \\ ${ }^{3}$ Department of Biology, Faculty of Science, Ankara University, Ankara, Turkey \\ ORCID ID: Mevlüde Alev ATEŞ: https:// orcid.org/0000-0002-2141-5438; Bahar KAPTANER İĞCİ: https:/ / orcid.org/0000-0001-7102-6337; \\ Tuğrul Selçuk KÖRÜKLÜ: https://orcid.org/0000-0002-7440-6818; Ahter Fİ̧NE: https://orcid.org/0000-0001-6895-8870; Zeki AYTAÇ: \\ https://orcid.org/0000-003-3244-3183
}

\begin{abstract}
Received: 16.05 .2019
Accepted: 24.06.2019

Published online: 30.06 .2019

Issue published: 30.06 .2019

Abstract: The genus Acantholimon Boiss. is comprised of approximately 200 species worldwide and represented with 71 taxa $56 \%$ of which are endemic in Turkey. Acantholimon anatolicum, A. ulicinum var. ulicinum, A. gemicianum, A. riyatguelii and A. acerosum var. acerosum are discussed in the current study due to their similar habitats. Although Acantholimon anatolicum, A. ulicinum var. ulicinum, A. gemicianum are morphologically and taxonomically very similar to each other, Acantholimon riyatguelii and $A$. acerosum var. acerosum are different than other species with scale (2-3 not 4-5) and scapes lengths. To understand the relationships among these taxa, morphological, palynological, and molecular structures were studied. Both LM and SEM were used to obtain the morphological characters and ITS nuclear gene region was amplified for molecular characteristics of taxa. According to the data, in addition to the morphological similarities there are also palynological and molecular similarities.
\end{abstract}

Keywords: Ecology, Flora, Systematic, Turkey.

\section{Benzer Yaşam Alanlarını Paylaşan Acantholimon Türlerinin (Plumbaginaceae) Morfolojik, Palinolojik ve Filogenetik İlişkileri}

Öz: Acantholimon Boiss cinsi. Dünya genelinde yaklaşık 200 tür ve 71 taksonla temsil edilir, bunların \%56'sı Türkiye için endemiktir. Bu çalışmada Acantholimon anatolicum, A. ulicinum var. ulicinum, A. gemicianum, A. riyatguelii ve A. acerosum var. acerosum benzer habitatları paylaşmaları nedeniyle karşılaştırılmıştır. Acantholimon anatolicum, A. ulicinum var. ulicinum, A. gemicianum morfolojik ve taksonomik olarak birbirlerine çok benzerdir. Ancak A. riyatguelii ve A. acerosum var. acerosum diğer türlerden skalalarınının 2-3 (4-5 değil) ve çiçeklenme boylarının yapraklardan uzun oluşuyla farklıdır. Bu taksonların ilişkilerini anlamak için morfolojik, palinolojik ve moleküler çalışmalar yapılmıştır. Morfolojik karakterleri elde etmek için hem ışık hem de elektron mikroskopu kullanılmış ve taksonların moleküler özellikleri için ITS nükleer gen bölgesi çalışılmıştır. Morfolojik benzerlikler verilerine ek olarak palinolojik ve moleküler veriler de benzerlik göstermektedir.

Anahtar kelimeler: Ekoloji, Flora, Sistematik, Türkiye.

\section{Introduction}

The genus Acantholimon Boiss. is comparised of approximately 200 species worldwide and most of them derived from its main diversity center Irano-Turanian Phytogeographic Region (Bokhari, 1970). The genus is represented with 25 species in Turkey. Moreover, 11 imperfectly known and unclearly recorded taxa were named as Acantholimon in Flora of Turkey (Bokhari and Edmondson, 1982). In recent years, the number of taxa has been increased up to 71 and forty of them were accepted as endemic. Therefore, the endemism ratio of the genus has become $56 \%$ in Turkey with recent studies (Akaydın \& Doğan, 2012; Doğan \& Akaydın, 2007; Yıldırım, 2009; Yıldırım, 2015; Kaptaner İğci, Körüklü, \& Aytaç, 2017; Akaydın, 2018).

In taxonomical studies, Acantholimon species are classified by using their morphological features like perennial, laxly or densely pulvinate subshubs forming thorn cushions. Furthermore, the genus members have got ecological and ornamental importance with nicely colored and long-lasting flowering periods (Muvaffak, Doğan, \& Bilgin, 2001). Due to its importance, there were many studies about the taxa. Although one of the revision studies was performed in Turkey about the breed resulted in a new taxon, members of the genus has not been clearly classified yet (Doğan and Akaydın, 2007).

In the current study, our purpose is to investigate the taxonomic positions of A. anatolicum Y1ld., A. gemicianum Kaptaner İ ̆̆ci, Körüklü \& Aytaç, and A. ulicinum (Willd. ex Schultes) Boiss. var. ulicinum A. acerosum (Willd.) Boiss. var. acerosum and $A$. riyatguelii Y1ldırım by using their morphological, palynological, and molecular structures through their shared habitats and their similar morphological structures.

The members of genus Acantholimon taxa usually preferred steppes, calcareous soils but some of them grow on serpentine main rocks. In this study, taxa grown in narrow areas and adapted to the gypsum soils were examined. A. anatolicum, A. gemicianum and A. riyatguelii have been identified in the last 10 years and they grow in 
gypsum soils. A. ulicinum var. ulicinum and A. acerosum var. acerosum grow in both calcareous and gypsum soils and share the same habitats. Therefore, similarities of these 5 taxa, relations, and morphological structures were aimed to be examined.

\section{Material and Methods}

\subsection{Morphological Studies}

For morphological and palynological analysis, the materials were collected from different parts of Ankara and Eskişehir provinces (Turkey) during flowering and fruiting times (Tab.1, Fig.1). The morphologic characters were investigated by light and scanning electron microscope. Until studying they were stored in GAZI.

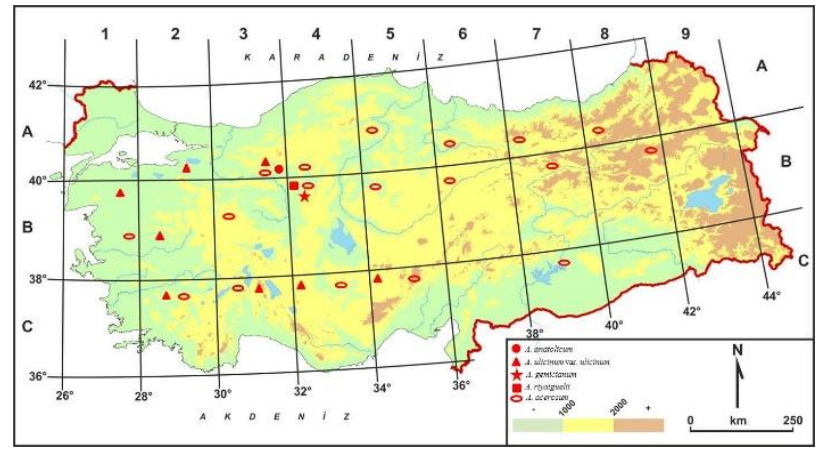

Figure 1: Distribution of the taxa in Turkey.

Tab. 1: Locations where the samples were collected and used in the studies.

\begin{tabular}{|c|c|c|}
\hline Species & Localities & $\begin{array}{l}\text { Collecter } \\
\text { number }\end{array}$ \\
\hline A. anatolicum & $\begin{array}{l}\text { Ankara: Beypazarı, Doğankonak } \\
\text { village, } 518 \mathrm{~m}, 13.07 .2017, \\
\text { calcareous-gypsum steppe. }\end{array}$ & $\begin{array}{l}\text { Körüklü } \\
22015 \text { \& } \\
\text { Aytaç }\end{array}$ \\
\hline $\begin{array}{l}\text { A. ulicinum } \\
\text { var. ulicinum }\end{array}$ & $\begin{array}{l}\text { Ankara: Beypazarı-Sekli road, } 690 \\
\mathrm{~m}, 13.07 .2017 \text {, calcareous steppe. }\end{array}$ & $\begin{array}{l}\text { Körüklü } \\
22018 \text { \& } \\
\text { Aytaç }\end{array}$ \\
\hline A. gemicianum & $\begin{array}{l}\text { Eskişehir: Sivrihisar, Balıkdamı, } \\
\text { Ahiler-Kurtşeyh,14. 07. 2017, } \\
\text { calcareous-gypsum steppe. }\end{array}$ & $\begin{array}{l}\text { Körüklü } \\
22023 \& \\
\text { Aytaç }\end{array}$ \\
\hline A. riyatguelii & $\begin{array}{l}\text { Eskişehir: Sivrihisar, Balıkdamı, } \\
\text { above Ertuğrulköy, } 900 \text { m,14. } 07 . \\
\end{array}$ & $\begin{array}{l}\text { Körüklü } \\
22021 \& \\
\text { Avtac }\end{array}$ \\
\hline A. acerosum & $\begin{array}{l}\text { Ankara: Beypazar1, Doğankonak } \\
\text { village, 13. 07. 2017, calcareous- } \\
\text { gypsum steppe. }\end{array}$ & $\begin{array}{l}\text { Körüklü } \\
\text { 22016\& } \\
\text { Aytaç }\end{array}$ \\
\hline
\end{tabular}

\subsection{Palynological Studies}

Pollen grains of five taxa were studied by using LM (Light Microscopy) and SEM (Scanning Electron Microscopy). Firstly, for the LM analysis, pollen grains were treated with $70 \%$ alcohol to remove oily substances around grains and they were embedded in glycerin jell and stained with basic fuchsin by following the method of Wodehouse (1959). At least 30 fully developed grains per sample were measured under a Leica ICC50 HD microscope (1000×) and polar axis $(\mathrm{P})$, equatorial axis $(\mathrm{E})$, and exine thickness (Ex) were analyzed. For all data, minimum, maximum, and mean \pm standard deviations were provided.

Additionally, for SEM analyses, pollen grains were transferred directly to stubs with double-sided adhesive tape and their micrographs were obtained using Jeol-6060 SEM at Gazi University at an accelerating voltage of $15 \mathrm{kV}$. Diameter of lumina and thickness of muri were also measured. For all analysis, the reference materials were stored at GAZI and ANK.

\subsection{Molecular Studies}

For molecular studies, leaf samples were obtained from natural habitats and optimized 2XCTAB method was used for total DNA isolation (Doyle 1990). The amplification of ITS region (ITS1+5.8S+ITS2) was done by using the primers of HsIao, Chatterton, Asay, \& Jensen, K (1995). For PCR amplifications 5x FIREPol $^{\circledR}$ Master Mix Ready to Load was used. The PCR reactions were performed with the steps of $95{ }^{\circ} \mathrm{C}$ for 5 min initial denaturation, followed by 30 cycle $95^{\circ} \mathrm{C}$ for $30 \mathrm{sec}$, annealing temperature for 30 sec, $72{ }^{\circ} \mathrm{C}$ for $90 \mathrm{sec}$ and $72{ }^{\circ} \mathrm{C}$ for $10 \mathrm{~min}$ as final extension. All the products were checked by using agorose jel (1.5\%) and all purification and sequencing of samples were performed by RefGEN Biotechnology company (Ankara). All sequences were formed for the analysis by editing null bases composed of unsuccessful nucleotide peaks from raw data that were examined by Finch TV software Version 1.4.0-manufactured by Geopiza Research Team; (Patterson, Chamberlain, \& Thayer, 2004-2006). The sequences were aligned by MUSCLE (Multiple Sequence Comparison by Log Expectation) tool (Edgar, 2004) of MEGA (Molecular Evolutionary Genetics Analysis) 7.0.9 software (Kumar, Stecher, \& Tamura, 2016). Additionally, for constructing the phylogenetic tree, neighbor-joining (NJ) method (Saitou \& Nei, 1987) which is the basic type of minimum evolutionary (ME) method, was used with bootstrap test analysis in MEGA software.

For all the samples studied, plants belonging to the collector number in the table are given.

\section{Results}

\subsection{Morphological Features}

The general morphological characteristic features of investigated species are being pulvinate, sub-shurblet, and glaucous (Fig. 2). Although A. anatolicum, A. ulicinum var. ulicinum and $A$. gemicianum are very similar to each other in morphological appearance; $A$. anatolicum leaves are glabrous and ciliate on their margins. Moreover, margins are glabrous or sparsely pubescent and scabrid in A. ulicinum var. ulicinum whereas they are puberulent in $A$. gemicianum. Leaf scapes are 5-8 cm long, branched, and represented in number $4-5$ in A. anatolicum scapes. Although the scales are absent in A. ulicinum var. ulicinum, they are shorter in A. gemicianum. Even though the number of spikletes is 6-12 in A. anatolicum; it is 3-7 in A. ulicinum var. ulicinum and 3-5 in A. gemicianum. Additionally, spikletes' numbers are 7-20 in A. riyatguelii whereas 5-15 in A. acerosum var. acerosum (Tab. 2).

Unlike all the other species, A. acerosum var. acerosum has a wide range of habitat as steppe, calcareous soil, rocky igneus slopes, and sandy soil due to its large ecological tolerance. In the shed light on these, intra-species variations are quite extensive in the species. Although other species are in narrow habitats, intra-species variation is not seen between them.

\subsubsection{Pollen Morphology}

The size range of polar axis $(\mathrm{P})$ varies between $46 \mu \mathrm{m}$ (in A. ulicinum var. ulicinum) and $81,6 \mu \mathrm{m}$ (in A. Acerosum var. acerosum), while the size range of equatorial axis (E) varies 
between $46 \mu \mathrm{m}$, (in A. Anatolicum) and 92,1 $\mu \mathrm{m}$ (in $A$. acerosum var. acerosum) (Tab. 3 ). Additionally, the shapes of pollen grains are oblate spheroidal, and all studied taxa have tricolpate apertures. Exine sculpturing (ornamentation) that was examined with SEM shows that pollen surface ornamentation is reticulate in all taxa. Furthermore, thickness of exine is close to each other in all taxa and its thickness ranges between 3,4 $\mu \mathrm{m}$ and 9,6 $\mu \mathrm{m}$ (Tab. 3). Although the diameter of the lumina is less than $3 \mu \mathrm{m}$ in A. acerosum var. acerosum and A. gemicianum, it is lower than in other taxa. The lumina diameter is greater than $6 \mu \mathrm{m}$ in A. anatolicum, A. ulicinum var. ulicinum and A. riyatguelii. Muri thickness is greater than $1 \mu \mathrm{m}$ in $A$. anatolicum and A. ulicinum var. ulicinum and A. Riyatguelii. However, it is smaller than $1 \mu \mathrm{m}$ in A. acerosum var. acerosum and A. gemicianum. According to our morphological results, it was determined that the pollen grains of $A$. acerosum var. acerosum was larger than other taxa, whereas the diameter of the lumina and the thickness of the muri were considerably smaller than those of all other pollen grains except $A$. gemicianum. The pollen grains of $A$. acerosum var. acerosum are larger than A. gemicianum, but other characters are similar to A. gemicianum. Furthermore, A. acerosum morphological features are significantly different from the other taxa (sect. Caryophylacea Bunge.). When we evaluate all these data, it is seen that $A$. acerosum var. acerosum has a different pollen that separates it from the other taxa systematically. (Tab. 2; Fig. 3).



Figure 2: General habitat appearance of plants. (a) A. anatolicum. (b) A. ulicinum var. ulicinum. (c) A. gemicianum. (d) A. riyatguelii. (e) A. acerosum.

\subsubsection{Molecular Data}

ITS region of DNA was examined in the current study. After amplification, $644 \mathrm{bp}$ were analyzed in total. 606 of them are conserved base pairs and 34 of them were variable within species. Most of the variable sites (28 bp) were informative for parsimony analysis. When the overall mean genetic divergence was calculated, the value reached to 0.024 that shows these species are genetically very close to each other. The genetic divergence was different among species. A. acerosum var. acerosum was very distinct from other species (0.0505); however, the closest similarity was seen between $A$. anatolicum, $A$. gemicianum and A. ulicinum var. ulicinum (0). To construct phylogenetic tree, Plumbago europaea (AB979599.1) was selected for the outgroup and its sequences of ITS regions were obtained from NCBI databank. As seen in the figure, first of all species are divided into 2 main clusters.



Figure 3: SEM micrographs of pollen grains in the Acantholimon taxa examined. (a-c) A. anatolicum. (d-f) A. ulicinum var. ulicinum (g-1) A. gemicianum (j-1) A. riyatguelii (m-o) A. acerosum.

The evolutionary history was inferred using the Neighbor-Joining method. The percentage of the replicate trees in which the associated taxa were clustered together in the bootstrap test (1000 replicates) are shown next to the branches. The tree is drawn to scale with branch lengths in the same units as those of the evolutionary distances used to infer the phylogenetic tree. The evolutionary distances were computed using the Kimura 2-parameter method and are in the units of the number of base substitutions per site. This analysis involved 6 nucleotide sequences. All ambiguous positions were removed for each sequence pair (pairwise deletion option). There was a total of 644 positions in the final dataset. Evolutionary analyses were conducted in MEGA 7.0.9.)

One of the main clusters composed of 2 species $A$. acerosum var. acerosum and $A$. riyatguelii. A. acerosum var. acerosum had clear insertions (4bp). Although these 2 species were positioned in the same cluster, A. acerosum var. acerosum was very distinct than $A$. riyatguelii, due to its specific insertions. On the other hand, the other cluster is composed of other 3 species A. ulicinum var. ulicinum A. 
gemicianum and A. anatolicum. Although A. ulicinum var. ulicinum and $A$. anatolicum species were located at the same subcluster, A. gemicianum was not very distinct than others. This means that, there were low number of base substitutions resulted in the separation of this subcluster (Fig. 4). Moreover Moharrek et al. (2014) reported that the genetic divergence between the Acantholimon species was very close to each other according to ITS sequences (0.02).

Table 2: Morphological comparison of species.

\begin{tabular}{|c|c|c|c|c|c|}
\hline & A. anatolicum & A. ulicinum var. ulicinum & A. gemicianum & A. riyatguelii & A. acerosum \\
\hline Habitus & $\begin{array}{l}\text { Densely pulvinate, } \\
\text { glaucous shrublet }\end{array}$ & $\begin{array}{l}\text { Densely pulvinate, calca- } \\
\text { reous-punctate shrublet }\end{array}$ & $\begin{array}{l}\text { Densely pulvinate, } \\
\text { glaucous shrublet }\end{array}$ & $\begin{array}{l}\text { Laxly dwarf caespitose, } \\
\text { pale-green to glaucous } \\
\text { Swollen-fleshy, linear } \\
\text { to }\end{array}$ & $\begin{array}{l}\text { Densely pulvinate, } \\
\text { glaucous shrublet }\end{array}$ \\
\hline Leaves & $\begin{array}{l}\text { Linear-triquetrous, } 5 \text { - } \\
12 \times 0.5-1 \mathrm{~mm} \text {, glabrous, } \\
\text { ciliate on margins }\end{array}$ & $\begin{array}{l}\text { Linear-triquetrous, } 5- \\
20 \times 1-1.2 \mathrm{~mm} \text {, glabrous or } \\
\text { sparsely pubescent }\end{array}$ & $\begin{array}{l}\text { Linear-triquetrous, } 7-10 \times \\
0.5-1 \mathrm{~mm} \text {, puberulent, } \\
\text { calcareous punctate }\end{array}$ & $\begin{array}{l}\text { oblong-linear, } 3-8 \times \\
1.5-2 \mathrm{~mm} \text {, mucronate, } \\
\text { pilose (mostly on } \\
\text { margins), calcareous- } \\
\text { punctate }\end{array}$ & $\begin{array}{l}\text { Linear or plano- } \\
\text { triquetrous, } 15-60 \times \\
0.8-2.2 \mathrm{~mm}\end{array}$ \\
\hline Scapes & 5-8 cm long, branched & Very short or \pm absent & 2-5 cm long, branched & $\begin{array}{l}\text { Simple, } 0.8-1.5 \mathrm{~cm} \text {, } \\
\text { densely puberulent, as } \\
\text { long as or slightly } \\
\text { exceeding leaves }\end{array}$ & $\begin{array}{l}\text { Simple, longer than } \\
\text { leaves }\end{array}$ \\
\hline Scales & $\begin{array}{l}4-5, \text { shorter than } \\
\text { internodes, strigillose all } \\
\text { over }\end{array}$ & Absent & $\begin{array}{l}2-3 \text {, shorter than } \\
\text { internodes, strigillose all } \\
\text { over }\end{array}$ & $\begin{array}{l}2-3 \text {, pilose, not } \\
\text { overlapping, the } \\
\text { lowermost shorter than } \\
\text { internodes }\end{array}$ & \\
\hline Spikes & $\begin{array}{l}2-3,15-20 \mathrm{~mm} \text { long, } \\
\text { imbricate or terminal }\end{array}$ & $\begin{array}{l}\text { 1-2, imbricate or densely } \\
\text { distichous }\end{array}$ & $\begin{array}{l}3-5,15-20 \mathrm{~mm} \text { long, } \\
\text { imbricate }\end{array}$ & $\begin{array}{l}\text { Solitary, densely } \\
\text { distichous, 15-40 mm } \\
\text { long }\end{array}$ & $\begin{array}{l}\text { Usually laxly } \\
\text { distichous, longer } \\
\text { than leaves }\end{array}$ \\
\hline Spikelets & $\begin{array}{l}\text { 6-12 in each spike, 1- } \\
\text { flowered, } 12-13 \mathrm{~mm}\end{array}$ & $3-7$ & $\begin{array}{l}3-5 \text { in each spike, } 1- \\
\text { flowered, } 12-13 \mathrm{~mm}\end{array}$ & $7-20,12-14 \mathrm{~mm}$ long & $5-15$ \\
\hline $\begin{array}{l}\text { Outer } \\
\text { bracts }\end{array}$ & $\begin{array}{l}\text { Unequal, puberulent all } \\
\text { over, } 4-5 \mathrm{~mm} \text { (including } \\
\text { aristate point), ovate, } \\
\text { narrowly hyaline on } \\
\text { margin }\end{array}$ & $\begin{array}{l}\text { Glabrous or pubescent, } \\
\text { oblong-lanceolate }\end{array}$ & $\begin{array}{l}\text { Unequal, puberulent } \\
\text { purplish apex, } 4-5 \mathrm{~mm} \\
\text { (including aristate point), } \\
\text { ovate, narrowly hyaline } \\
\text { on margin }\end{array}$ & $\begin{array}{l}6-7 \text { mm long, ovate, } \\
\text { cuspidate, densely } \\
\text { pilose, } \\
\text { calcareouspunctate, } \\
\text { narrow hyaline } \\
\text { margins }\end{array}$ & $\begin{array}{l}\text { Equal to shorter than } \\
\text { inner, triangular- } \\
\text { lanceolate, } 5-10 \mathrm{~mm} \text {, } \\
\text { with narrow hyaline } \\
\text { margin }\end{array}$ \\
\hline $\begin{array}{l}\text { Inner } \\
\text { bracts }\end{array}$ & $\begin{array}{l}7-7.5 \mathrm{~mm} \text { (including aristate } \\
\text { point c. } 1 \mathrm{~mm} \text { ), oblong- } \\
\text { lanceolate, obtuse, cuspidate } \\
\text { with narrowly hyaline margin }\end{array}$ & $\begin{array}{l}\text { Acuminate, long } \\
\text { cuspidate cuspidate, } \\
\text { hyaline except for the } \\
\text { dark brown vein }\end{array}$ & $\begin{array}{l}7-7.5 \mathrm{~mm} \text { (including } \\
\text { aristate point c. } 1 \mathrm{~mm} \text { ), } \\
\text { oblong-lanceolate, obtuse } \\
\text { cuspidate with narrowly } \\
\text { hyaline margin }\end{array}$ & $\begin{array}{l}5-7 \mathrm{~mm} \text { long, } \\
\text { oblonglanceolate } \\
\text { to narrowly } \\
\text { lanceolate, cuspidate, } \\
\text { pilose on midrib, hyaline } \\
\text { except ribs }\end{array}$ & $\begin{array}{l}\text { Oblong-lanceolate, to } \\
\text { narrowly lanceolate, } \\
\text { obtuse to acute } \\
\text { cuspidate, with broad } \\
\text { hyaline margin }\end{array}$ \\
\hline Calyx & $\begin{array}{l}10-11 \mathrm{~mm} \text {, tube densely } \\
\text { pilose; limb } 10 \text {-lobed, } \\
\text { white; veins } 5 \text { - brownish, } \\
\text { pilose, expanded towards } \\
\text { margins, not excurrent }\end{array}$ & $\begin{array}{l}11-12 \mathrm{~mm} \text {, tube densely } \\
\text { pilose; limb obscurely } 5- \\
10 \text { lobed; veins purple, } \\
\text { expanded towards } \\
\text { margin, excurrent }\end{array}$ & $\begin{array}{l}\text { 10-11 mm, tube sparsely } \\
\text { pilose; limb 10-lobed, } \\
\text { white; veins 5-brownish, } \\
\text { pilose, expanded towards } \\
\text { margins, not excurrent }\end{array}$ & $\begin{array}{l}\text { 8-10 mm long, sparsely } \\
\text { pilose on ribs; limb 5- } \\
\text { lobed }\end{array}$ & $\begin{array}{l}\text { Calyx tube pillose on } \\
\text { veins, limb white or } \\
\text { pale flesh color, } \\
\text { usually } 5 \text { lobe }\end{array}$ \\
\hline Habitat & $\begin{array}{l}\text { Deep sandy gypsum-rich } \\
\text { soil }\end{array}$ & $\begin{array}{l}\text { Deep marl-gypsum, eroded } \\
\text { hills }\end{array}$ & $\begin{array}{l}\text { Deep marl-gypsum-rich } \\
\text { soil }\end{array}$ & Gypsum-rich soils & Calcareous steppe \\
\hline
\end{tabular}

Table 3: Summary of pollen morphological data for the Acantholimon taxa examined.

\begin{tabular}{|c|c|c|c|c|c|c|}
\hline Taxa & $\mathbf{P}(\mu \mathrm{m})$ & $\mathrm{E}(\mu \mathrm{m})$ & Pollen shape & Exine thickness & Diameter of lumina & Thickness of muri \\
\hline A. anatolicum & $\begin{array}{l}(53,7-) 57 \pm 2,3 \\
(-62,4)\end{array}$ & $\begin{array}{l}(46-) 59,8 \pm 3,4 \\
(-65,2)\end{array}$ & oblate - spheroidal & $\begin{array}{l}(6,7-) 8,1 \pm 0,8 \\
(-9,6)\end{array}$ & $\begin{array}{l}(5,4-) 6,5 \pm 1,5 \\
(-11,3)\end{array}$ & $\begin{array}{l}(2-) 2,1 \pm 0,1 \\
(-2,2)\end{array}$ \\
\hline A. ulicinum var. ulicinum & $\begin{array}{l}(46-) 58 \pm 5,8 \\
(-68,1)\end{array}$ & $\begin{array}{l}(51,8-) 63,9 \pm 6,4 \\
(-79,6)\end{array}$ & oblate - spheroidal & $\begin{array}{l}(5,7-) 7 \pm 0,9 \\
(-8,6)\end{array}$ & $\begin{array}{l}(5,5-) 7,7 \pm 1,6 \\
(-10,6)\end{array}$ & $\begin{array}{l}(2-) 2,1 \pm 0,1 \\
(-2,3)\end{array}$ \\
\hline A. gemicianum & $\begin{array}{l}(55,6-) 58 \pm 1,7 \\
(-61,4)\end{array}$ & $\begin{array}{l}(59,5-) 62,6 \pm 1,4 \\
(-66,2)\end{array}$ & oblate -spheroidal & $\begin{array}{l}(3,4-) 5,7 \pm 0,8 \\
(-7,6)\end{array}$ & $\begin{array}{l}(1-)) 1,8 \pm 0,6 \\
(-4,1)\end{array}$ & $\begin{array}{l}(0,4-) 0,6 \pm 0.1 \\
(-0,8)\end{array}$ \\
\hline A. riyatguelii & $\begin{array}{l}(47-) 52,9 \pm 2,5 \\
(-57)\end{array}$ & $\begin{array}{l}(51,8-) 57,3 \pm 3,2 \\
(66,6)\end{array}$ & oblate - spheroidal & $\begin{array}{l}(5,7-) 7 \pm 0,9 \\
(-8,6)\end{array}$ & $\begin{array}{l}(5,9-) 9,8 \pm 2,5 \\
(-15,1)\end{array}$ & $\begin{array}{l}(0,8-) 1,1 \pm 0,1 \\
(-1,6)\end{array}$ \\
\hline A. acerosum & $\begin{array}{l}(66,2-) 71,4 \pm 4,6 \\
(-81,6)\end{array}$ & $\begin{array}{l}(72-)) 77,9 \pm 4,8 \\
(-92,1)\end{array}$ & oblate - spheroidal & $\begin{array}{l}(4,8-) 5,5 \pm 0,6 \\
(-6,7)\end{array}$ & $\begin{array}{l}(1,7-) 2,7 \pm 0,5 \\
(-4)\end{array}$ & $\begin{array}{l}(0,4-) 0,8 \pm 0,2 \\
(-1,7)\end{array}$ \\
\hline
\end{tabular}

\section{Discussion}

\subsection{Morphological Studies}

As a result of the obtained data, it could be said that Acantholimon anatolicum, A. gemicianum, and A. ulicinum var. ulicinum werevery close to each other morphologically. Only some small differences in numbers of some morphological features separated these taxa from each other. For instance, A. ulicinum var. ulicinum was separated from other two taxa by its strigillose bracts, strongly glaucous leaves, and 2-3 in number of scales on scape and $A$. anatolicum was distinguished from $A$. gemicianum with 4-5 in number of scales on scape and ciliate margin with glabrous leaves (not puberulous and calcareous punctate).

\subsection{Palynological and Molecular Studies}

On the other hand, the pollen grains did not give significant criteria for their distinctions in taxa. Therefore, pollen characters could be partly used as taxonomic 
characters in order to distinguish the species in the taxa (Muvaffak et al. 2001). Moreover, it is seen that genetic similarities between A. anatolicum and A. gemicianum are very close to each other. In a phylogenetic study on the Plumbaginaceae family, the genus Acantholimon is seen as a separate clade (Koutroumpa et.al. 2018). Moharrek, Osaloo, \& Mostafa (2014) reported that genetic divergence between Acantholimon species was very close to each other according to ITS sequences (0.02). In our study, $A$. anatolicum and $A$. gemicianum were first studied phylogenetically. It is difficult to taxonomically classify those two taxa, which shared similar habitats and can be expected to have exchanged genes through hybridization. It could be more useful if more genetic regions belonging to the species that are morphologically close are studied in the future to understand the classification of the taxa.

When looking at the dendrogram, A. riyatguelii is located in the same branch with A. acerosum var. acerosum, although it grows in gypsum soils like A. anatolicum and A. gemicianum. This finding suggests that genetic similarities are not dependent to the gypsum rock type. So that, it should be investigated whether these species have selective characteristics related to main rock types which they grow.
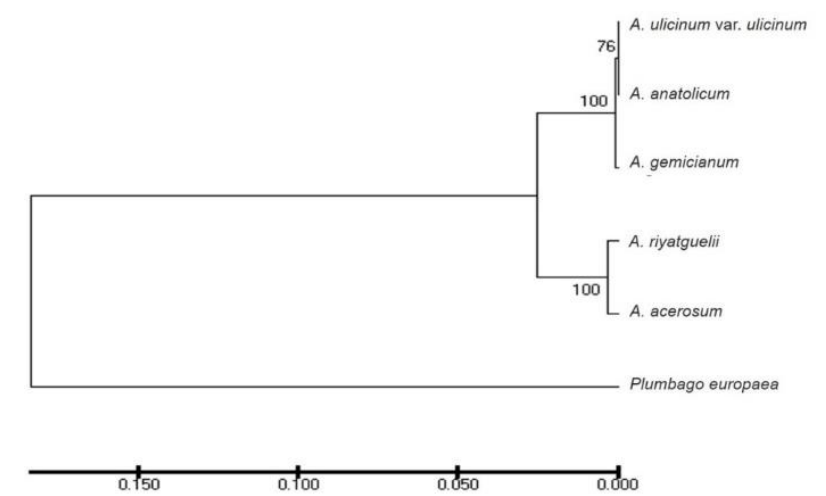

Figure 4: Phylogenetic dendrogram of ITS region drawn by using NJ method

\section{References}

Akaydın, G. \& Doğan, M. (2012). Acantholimon Boiss. in Güner A., Aslan S., Ekim T., Vural M. and Babaç T. (eds.). Türkiye Bitkileri Listesi (Damarlı Bitkiler). Nezahat Gökyiğit Botanik bahçesi ve Flora Araştırmaları Derneği Yayını.

Akaydın, G. (2018). Acantholimon ibrahimii (Plumbaginaceae), a new species of A. section Staticopsis from the Mediterranean part of Turkey. Phytotaxa 340(1), 48-54.

Bokhari, M. H. \& Edmondson, J. R. (1982). Acantholimon Boiss., in Flora of Turkey and the East Aegean Islands. Edinburh U. Press. 7, 478-502.

Bokhari, M. H. (1970). Materials for a Flora of Turkey XXII. Plumbaginaceae. Notes Royal Botanic Garden 30, 295-304.

Doğan, M. \& Akaydın, G. (2007). Synopsis of Turkish Acantholimon Boiss. (Plumbaginaceae). Bot.J Linn. 154, 397-419.

Doyle, J. J. \& Doyle, J. L. (1987). A rapid DNA isolation procedure for small quantities of fresh leaf tissue. Phytochem. Bull. 19, 11-15.

Edgar, R. C. (2004). MUSCLE: multiple sequence alignment with high accuracy and high throughput. Nucleic acids research 32(5), 1792-1797.

HsIao, C., Chatterton, N. J., Asay, K. H. \& Jensen, K. B. (1995). Phylogenetic relationships of the monogenomic species of the wheat tribe, Triticeae (Poaceae), inferred from nuclear rDNA (internal transcribed spacer) sequences. Genome 38, 221-223.

Kaptaner İğci, B., Körüklü, S. T. \& Aytaç, Z. (2017). Acantholimon gemicianum (Plumbaginaceae), A New Species from Turkey. Ann. Bot. Fenn. 54(13), 83-88.

Koutroumpa K, Theodoridis S, Warren B, Jiménez A, Celep F, Doğan M, Romeiras M, Santos-Guerra A, Fernández-Palacios J, Caujapé-Castells
J, Moura M, Menezes de Sequeira M, Conti E. (2018). An expanded molecular phylogeny of Plumbaginaceae, with emphasis on Limonium (sea lavenders): Taxonomic implications and biogeographic considerations. Ecol Evol. 8(24):12397-12424.

Kumar, S., Stecher, G. \& Tamura. K. (2016). MEGA7: Molecular Evolutionary Genetics Analysis version 7.0 for bigger datasets. Molecular Biology and Evolution 33, 1870-1874.

Moharrek, F., Osaloo, S. K. \& Mostafa, A. M. (2014). Molecular phylogeny of Plumbaginaceae with emphasis on Acantholimon Boiss. based on nuclear and plastid DNA sequences in Iran. Biochemical Systematics and Ecology 57, 117-127.

Muvaffak, A., Doğan, M. \& Bilgin, C. (2001). A numerical taxonomic study of the genus Acantholimon Boiss. (Plumbaginaceae) in Ankara Province (Turkey). Israel J. Plant Sci. 49, 298-300.

Patterson, J., Chamberlain, B. \& Thayer, D. (2004-2006). Finch TV Version 1.4.0.

Saitou, N. (1987). The neighbor-joining method: A new method for reconstructing phylogenetic trees. Mol. Biol. Evol. 4, 406-425.

Wodehouse, R. P. (1959). Pollen grains. Hafner publishing Co, NewYork.

Yıldırım, H. \& Crespo, M. B. (2015). Acantholimon riyatguelii (Plumbaginaceae), a threatened new unarmed species from Central Anatolia, Turkey. Phytotaxa 175 (2), 73-84.

Yıldırım, Ş. (2009). Designation of holotype of Acantholimon anatolicum Doğan \& Akaydın (Plumbaginaceae). Ot Sist. Bot. 16, 1-14. 